\title{
PERANCANGAN SISTEM PENJUALAN TUNAI BERBASIS WEB SEBAGAI SARANA INFORMASI PRODUK BAGI KONSUMEN PADA PT. WARNA AC
}

Oleh:

YUWANDITO WIHARJANTO

NIM : 08412141016

\begin{abstract}
Abstrak
Penelitian Ini bertujuan (1) mengetahui sistem penjualan tunai pada perusahaan Warna $\mathrm{AC}$, dan (2) merancang sistem penjualan tunai berbasis web yang sesuai untuk perusahaan Warna AC guna memberikan sarana informasi produk bagi konsumen.

Penelitian ini termasuk jenis penelitian pengembangan. Subjek penelitian ini adalah perusahaan Warna AC yang bertempat di Jalan Pemancar Selatan no. 153 Seturan Caturtunggal Depok Sleman Yogyakarta. Objek dalam penelitian ini adalah sistem penjualan tunai. Data diperoleh dengan metode wawancara,observasi,dan analisis dokumen. Pengembangan sistem penjualan tunai berbasis web menggunakan metode SDLC sebagai berikut; (a) Analisis sistem terdiri dari analisis kelemahan sistem lama,analisis kebutuhan sistem, dan analisis kelayakan sistem; (b) Desain sistem penjualan tunai berbasis web meliputi desain sistem, desain program, desain fisik,dan desain antarmuka program; (c) Implementasi sistem penjualan tunai berbasis web.

Hasil penelitian ini menunjukkan bahwa (1) sistem penjualan yang diterapkan pada perusahaan Warna

keluar sehingga menyebabkan kurangnya informasi; (c) Bagan alir sistem penjualan pada perusahaan Warna AC tersusun atas fungsi penjualan, fungsi gudang,dan fungsi administrasi; (d) sistem pengendalian intern pada perusahaan Warna AC belum berjalan dengan baik dikarenakan masih terjadi perangakapan fungsi. (2) Perancangan sistem penjualan tunai berbasis web pada perusahaan Warna AC menggunakan metode SDLC meliputi; (a) Analisis sistem yang diterapkan menunjukkan bahwa sistem yang baru dikatakan layak secara teknik, operasional, ekonomi,dan hukum untuk dikembangkan karena telah memenuhi criteria dalam kelayakan sistem; (b) Hasil desain sistem penjualan tunai berbasis web meliputi bagan alir,catatan akuntansi dan dokumen dalam sistem tersebut; (c) Desain program sistem terdiri dari desain input, desain output, dan desain file dan database dengan mengunakan aplikasi macromedia dreamweaver dan MySQL,desain terdiri dari 5 form dan 7 tabel; (d) Implementasi menggunakan metode konversi paralel sehingga memudahkan karyawan dan meminimalisir kesalahan tagihan. Kendala yang dihadapi yaitu keterbatasan jumlah pegawai dalam melaksanakan sistem tersebut.
\end{abstract} AC masih sederhana yang meliputi; (a) Fungsi yang terkait dengan sistem penjualan tunai meliputi bagian gudang,bagian penjualan, bagian administrasi; (b) Dokumen dan catatan sistem penjualan meliputi nota penjualan, laporan penjualan, laporan penerimaan kas,laporan barang
Kata Kunci : Penjualan Tunai, SDLC, Perancangan,Sistem Penjualan Tunai,Web. 


\section{Jurnal Nominal / Volume I Nomor I / Tahun 2012}

\section{A. PENDAHULUAN}

\section{Latar Belakang}

Perkembangan Dunia Usaha saat ini menjadikan informasi sebagai pilar penting dalam berjalannya kegiatan operasional suatu usaha demi tercapainya tujuan yang diinginkan oleh pengusaha tersebut. Bagi keberlangsungan usaha,pengetahuan akan informasi suatu produk adalah hal yang sangat penting dalam pengambilan keputusan untuk pembelian produk yang ditawarkan oleh suatu perusahaan, secara lengkap,relevan dan akurat. Tidak memandang apakah perusahaan tersebut kecil atau besar.

Sarana internet adalah salah satu media informasi yang efektif dan efisien dalam penyampaian informasi yang dapat pula diakses oleh setiap orang, dimana saja dan kapan saja. Media Internet sangat berpengaruh dalam dunia bisnis dan perdagangan. Selain itu teknologi internet sudah tidak asing lagi bagi beberapa pengusaha dan pelaku bisnis. Saat ini para pengusaha sudah banyak yang sudah memanfaatkan media internet sebagai sarana penginformasian produk yang dijual serta perbaikan pelayanan pelanggan, hal tersebut dilakukan semata - mata untuk meningkatkan omset penjualan mereka, mengingat dunia maya tidak mengenal batasan ruang dan waktu.

Perusahaan Warna AC adalah UKM yang bergerak dibidang penjualan berbagai macam, alat pendingin terutama AC bekas maupun baru. Produk perusahaan pada awalnya dipasarkan kepada semua instansi pemerintah maupun swasta yang ada di Yogyakakarta. Seiring dengan perkembangan teknologi maka penjualan ke instansi-instansi tersebut mengalami penurunan dikarenakan kalah bersaing dengan perusahaan lain yang sejenis.
Perusahaan Warna AC merupakan perusahaan yang sedang dalam proses pengembangan pasar, dimana masih banyak UKM yang belum menggunakan sistem penjualan melalui internet atau E-Commerce. Sistem penjualan tunai yang selama ini digunakan oleh Warna AC adalah memakai sistem penjualan tunai secara manual sehingga kinerjanya belum efektif dikarenakan terjadi penumpukan arsip yang tidak teratur

Pada sisi lain pelanggan mengalami kesulitan untuk memperoleh informasi mengenai jenis barang, gambar, ketersediaan, deskripsi produk, dan informasi harga produk merupakan salah satu kendala yang dihadapi selama penggunaan sistem konvensional. Untuk melihat informasi mengenai produk yang dibutuhkan, pelanggan harus datang ke toko untuk mengetahui informasi secara mendetail. ini menyebabkan banyak waktu terbuang yang dibutuhkan pelanggan untuk memperoleh informasi. Selain itu untuk melakukan pembelian, pelanggan juga dipersulit dengan tidak adanya sistem yang mempermudah pelanggan untuk melakukan pembelian selain dengan datang langsung ke toko. Kendala seperti ini akan berdampak pada berkurangnya niat pelanggan untuk melakukan transaksi

Oleh karena itu akan dirancang suatu sistem penjualan tunai berbasis web yang mudah digunakan dan dipahami oleh pengusaha, sehingga sistem penjualan tunai pada Warna AC menjadi sebuah informasi modern yang terkomputerisasi dengan baik guna mengatasi segala permasalahan tersebut. Penggunaan penjualan tunai berbasis web tersebut diperlukan dalam jangka panjang guna meningkatkan kualitas informasi yang dihasilkan oleh sistem seperti kecepatan, keakuratan, dan ketepatan waktu. Pada akhirnya, bersa- 


\section{Jurnal Nominal / Volume I Nomor I / Tahun 2012}

maan dengan peningkatan kualitas informasi tersebut, juga diharapkan dapat memperbaiki kinerja perusahaan menjadi lebih baik serta untuk menanggapi kebutuhan pelanggan akan informasi penjualan tunai secara lebih luas yang berujung pada peningkatan omzet penjualan perusahaan.

Dengan memanfaatkan perkembangan teknologi saat ini penulis tertarik untuk meneliti mengenai system penjualan tunai yang berbasis web. Sehingga judul penelitian yang diambil adalah "Perancangan Sistem Penjualan Tunai Berbasis Web Sebagai Sarana Informasi Produk Bagi Konsumen pada PT. Warna AC" Dengan adanya sistem tersebut diharapkan dapat memberikan kemudahan dalam memperoleh informasi yang dibutuhkan.

\section{B. METODE PENELITIAN}

Sistem penjualan tunai berbasis web adalah sistem serta prosedur yang mengorganisasi formulir, catatan, laporan dan transaksi yang berhubungan dengan kegiatan penjualan perusahaan yang berasal dari transaksi penjualan tunai atau transaksi lain yang dapat menambah kas perusahaan dengan menggunakan suatu media agar dapat menyediakan informasi yang dibutuhkan manajemen.

Penelitian ini dilaksanakan di Perusahaan Warna AC, yang beralamat di Perum Deppen no. 153 Seturan Caturutnggal Depok Sleman, Daerah Istimewa Yoyakarta. Pelaksanakan penelitian dimulai pada bulan $\mathrm{M}$ aret 2012.

Desain penelitian dalam penelitian ini adalah Research and Development (R\&D) atau Penelitian dan Pengembangan. Research and Development adalah penelitian yang bertujuan mengembangkan produk sehingga produk tersebut mempunyai kualitas yang lebih tinggi. Dalam penelitian ini akan dilakukan proses merancang sistem penjualan tunai berbasis web pada PT. Warna AC yang merupakan perkembangan dari e-commerce atau penjualan secara online dengan sarana internet. Subjek penelitian ini adalah PT. Warna AC. Sedangkan objek penelitiannya adalah sistem penjualan tunai sebagai sarana informasi produk bagi konsumen.

\section{HASIL PENELITIAN}

1 Sistem Penjualan Tunai yang Diterapkan pada Perusahaan Warna AC

a. Dokumen dan Catatan akuntansi yang digunakan dalam sistem penjualan tunai pada Perusahaan Warna AC meliputi Laporan Penjualan,Laporan Penerimaan Kas,Laporan barang keluar, sedangkan dokumen yang digunakan satu - satunya adalah nota penjualan,

b. Prosedur sistem penjualan tunai yang diterapkan di Perusahaan Warna AC meliputi prosedur booking mobil, prosedur penjualan, prosedur pencatatan dan prosedur gudanng dan pengiriman.

c. Fungsi yang terkait dalam sistem penjualan tunai yang diterapkan pada Perusahaan Warna AC meliputi fungsi penjualan,administrasi dan fungsi teknisi/gudang/pengiriman.

Penelitian ini dilaksanakan di Perusahaan Warna AC, yang beralamat di Perum Deppen no. 153 Seturan Caturutnggal Depok Sleman, Daerah Istimewa Yoyakarta. Pelaksanakan penelitian dimulai pada bulan $\mathrm{M}$ aret 2012. 


\section{Jurnal Nominal / Volume I Nomor I / Tahun 2012}

Desain penelitian dalam penelitian ini adalah Research and Development (R\&D) atau

Penelitian dan Pengembangan. Research and Development adalah penelitian yang bertujuan mengembangkan produk sehingga produk tersebut mempunyai kualitas yang lebih tinggi. Dalam penelitian ini akan dilakukan proses merancang sistem penjualan tunai berbasis web pada PT. Warna AC yang merupakan perkembangan dari ecommerce atau penjualan secara online dengan sarana internet. Subjek penelitian ini adalah PT. Warna AC. Sedangkan objek penelitiannya adalah sistem penjualan tunai sebagai sarana informasi produk bagi konsumen.

2 Analisis Sistem Penjualan Tunai Berbasis Web Perusahaan Warna AC

\section{a. Analisis Kelemahan Sistem Lama}

Proses pencatatan dan perhitungan transaksi pelanggan yang dilakukan secara manual, sehingga waktu untuk melakukan tersebut menjadi lama. Pencatatan transaksi ditulis pada media kertas, sehingga membutuhkan banyak kertas untuk setiap hari transksinya. Jadi biaya untuk melakukan pencatatan transaksi menjadi lebih besar. Kurang lengkapnya dokumen dan catatan akuntansi maupun sistem otorisasi menyebabkan ketidak sesuaian informasi penjualan yang dihasilkan pada sistem yang berjalan saat ini.

\section{b. Analisis Kebutuhan Sistem}

Sistem yang akan dirancang harus dapat melakukan input dan edit data pelanggan, dan data barang dagang. Sistem harus dapat melakukan penyimpanan data transaksi. Sistem harus dapat menampilkan laporan transaksi penjualan kepada pemilik perusahaan. c. Analisis Kelayakan sistem Baru

Kelayakan sistem dilakukan dengan melakukan analisis ekonomi yang meliputi analisis PP (Payback Period), dalam perhitungan analisis PP didapatkan hasil 0,90 artinya nilai investasi akan kembali dalam waktu 10 bulan 29 hari. Waktu pengembalian tersebut kurang dari 3 tahun, sehingga proyek ini layak untuk dijalankan.

Berdasarkan hasil analisis dengan metode ROI (Return On Investment) didapatkan hasil sebesar

134,59 \%. Hasil ini lebih besar dari 0 (nol) sehingga proyek ini layak untuk dikembangkan.

Berdasarkan hasil analisis dengan metode NPV (Net Present Value) dengan tingkat suku bunga sebesar $6,75 \%$ didapatkan nilai sebesar Rp. 2.936.850. Hasil tersebut bernilai positif sehingga proyek ini layak untuk dijalankan.

3 Desain Sistem Penjualan Tunai Berbasis Webpada Perusahaan Warna AC

Dalam pemodelan proses meliputi beberapa proses yaitu input data produk, input data pelanggan, tampilkan laporan data pelanggan, tampilkan laporan data produk, tampilkan data order, tampilkan laporan penjualan perbulan, tampilkan laporan penjualan per barang,dan laporan penjualan secara keseluruhan..

Pemodelan interface terdiri dari beberapa tampilan program, meliputi menu utama, form login,

form tambah produk, form pelanggan, form pembayaran. 


\section{Jurnal Nominal / Volume I Nomor I / Tahun 2012}

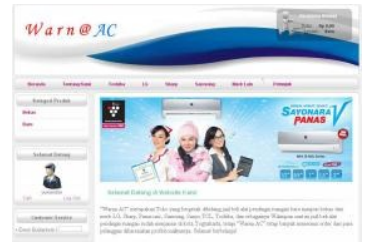

Gambar 1.

Menu

Utama

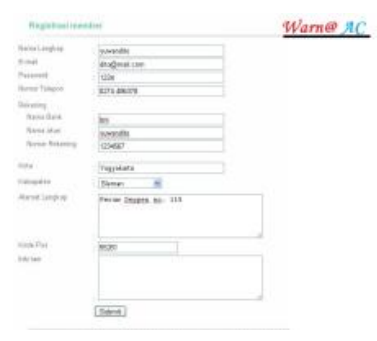

Gambar 3

Form

Pelanggan

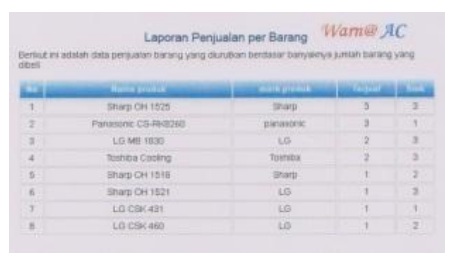

Gambar 5.

Laporan

Penjualan

Per Barang

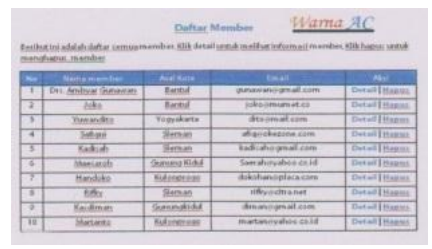

Gambar 7.

Daftar

Member

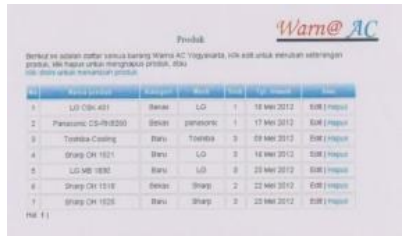

Gambar 2.

Laporan

Koleksi

Produk

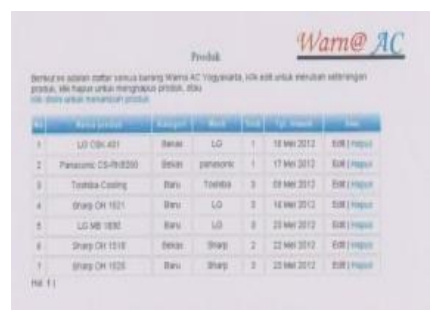

Gambar 4.

Form Tam-

bah Produk

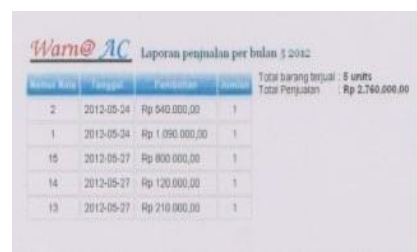

Gambar 6.

Laporan

Penjualan

Per Bulan

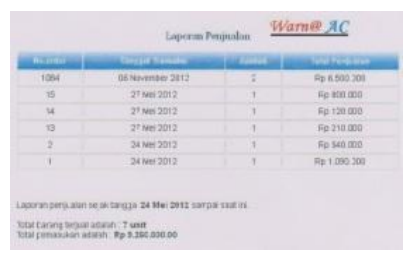

Gambar 8.

Laporan

Penjualan

4 Implementasi Sistem Penjualan Tunai Berbasis

Web pada Perusahaan Warna AC

Bagian yang dipilih sebagai operator sistem adalah bagian administrasi. Pada kegiatan konversi sistem, dipilih model paralel yaitu dengan melakukan im-

plementasi sistem Penjualan Tunai Berbasis Web secara bersamaan dengan pemakaian sistem penjualan tunai manual selama jangka waktu 3 hari.

Kendala yang dihadapi dalam proses konversi, yaitu pada awal-awal dilakukan konversi sistem pengguna sistem masih bingung tentang prosedurprosedur input data serta jumlah karyawan yang kurang.

Tindaklanjut implementasi dilakukan dengan evaluasi, yaitu evaluasi kinerja sistem dan evaluasi sumberdaya. Kinerja sistem dinilai sukses, karena telah tersimpannya data-data yang telah di input pada saat pengujian sistem. Sumberdaya perusahaan dinilai mampu menjalankan sistem karena bagian resepsionis telah mampu mengoperasionalkan sistem.

\section{PENUTUP}

\section{Kesimpulan}

a. Sistem penjualan yang diterapkan pada perusahaan Warna AC masih bersifat manual dan masih sangat sederhana terutama dalam memberikan informasi untuk pengendalian intern perusahaan.

b. Dalam analisis sistem terdapat beberapa kelemahan, yaitu dokumen hanya mimiliki hanya satu saja yaitu nota penjualan, sehingga jika terjadi kehilangan data tidak ada data pengganti.

c. Perancangan/desain sistem Penjualan Tunai Berbasis Web dibuat dengan program Macromedia

Dreamweaver dan database PHPMySQL..

d. Pada Implementasi sistem, dipilih model paralel yaitu dengan melakukan implementasi sistem Penjualan Tunai Berbasis Web secara bersamaan 
dengan pemakaian sistem penjualan tunai manual selama jangka waktu 3 hari.

\section{E. DAFTAR PUSTAKA}

Ellsworth, Jill H. and Matthew V. Ellsworth. (1997). Pemasaran Di Internet. Tejemahan Yulianto.Grasindo, Jakarta

Hall,James A. (2007). Sistem Informasi Akuntansi, Edisi 4. Jakarta : Salemba Empat Hanif Al Fatta. (2007). Analisis dan Perancangan Sistem Informasi. Yogyakarta: Andi Offset

Jeffery L. Whitten, Lonnie D. Bentley dkk. (2004) . Metode Desain dan Analisis Sistem. Yogyakarta : Andi Jogiyanto. (1999). Analisa dan Desain Sistem Informasi. Yogyakarta: Andi Offset _.(2000). Sistem Informasi Berbasis Komputer. Yogyakarta : BPFE

Mcleod, Raymond. (2001). Sistem Informasi Manajemen. Edisi ke-tujuh : jilid 1. Jakarta : PT. Prenhallindo

Mulyadi, (2001). Sistem Akuntansi. Jakarta:Salemba Empat

Narko.(2007). Sistem Akuntansi, Cetakan Kelima. Yogyakarta: Yayasan Pustaka Nusatama

Nugroho Widjajanto.(2001). Sistem Informasi Akuntansi. Jakarta : Erlangga

O’Brien, James A. (2005). Pengantar Sistenm Informasi (ed.6). Jakarta : Salemba Empat

Sidik Betha. (2005). MYSQL. Bandung : Informatika

Turban, Efraim.(2000). Pengantar Teknologi Informasi. Jakarta : Salemba Empat

Wahidin.(2005). 7 Jam Belajar Dreamweaver MX
2004 untuk Orang Awam. Palembang : Maxikom

Santi. (2003). Perancangan Sistem Akuntansi Atas Transaksi Penjualan pada PT.Nobel Technotronics di Surabaya. Surabaya : Universitas Airlangga

Wily Indrajati. (2007). Perancangan Sistem Penjualan Terkomputerisasi pada PT. Sarang Madu. Jakarta : Universitas Pembangunan Nasional

Supeni. (2009). Perancangan Sistem Penjualan pada Kerajinan Batik KAyu Sanggar Peni Bantul. Yogyakarta : Universitas Negeri Yogyakarta Agus arwani.2008. Modul Pengantar Akuntansi. http://agusarwani.blogspot.com/2008/11/11/Modul -Pengantar akuntansi .html., diakses 23 Februari 2012 